\title{
Sufficiency Economy Philosophy Towards Poverty Eradication in Thailand
}

\author{
Phramaha Wattana Khamken ${ }^{1}$, Lampong Klomkul ${ }^{2}$, Chainarong Khaw-ngern ${ }^{3}$, Kannikar Khaw- \\ ngern $^{4}$ \\ ${ }^{1}$ Palisuksa Buddhagosa Campus, Mahachulalongkornrajavidyalaya University, \\ ${ }^{2}$ Faculty of Education, Mahachulalongkornrajavidyalaya University, \\ ${ }^{3}$ Faculty of Humanities, Mahachulalongkornrajavidyalaya University, \\ ${ }^{4}$ Faculty of Buddhism, Mahachulalongkornrajavidyalaya University \\ ${ }^{1}$ Wattanakhamken@gmail.com, ${ }^{2}$ research.mcu@gmail.com, ${ }^{3}$ chainarong.kha@ @mcu.ac.th, ${ }^{4}$ kannikar.khaw@gmail.com
}

\begin{abstract}
As of 2015, about 736 million people around the world still lived on poverty. Many of them lack of food, clean drinking water and sanitation. Due to economies shrink around the world and the coronavirus pandemic, millions of Thai people have been left in poverty. The purpose of this article is to examine the causes of increasing global poverty and the rising poverty in Thailand, to study the SDGs Goal 1 and its targets in eradicating poverty around the world, to explore the principles of Sufficiency Economy for poverty eradication and sustainable development in Thailand. Documentary study and literature review were used for data collection. The problems of economy shrink caused interruption in household incomes and consumption growth, and the coronavirus spread made unemployment rate and household debt rise which exacerbated the poverty situation. Results showed that Sufficiency Economy Philosophy (SEP) is an approach for sustainable development which espouses moderation, reasonableness and prudence as development framework based on knowledge and virtue. SEP principles are aligned with the principles and objectives of SDGs, seeking to eradicate poverty and reduce inequality as a means to achieve sustainable development. Applications of Sufficiency Economy Philosophy have proved for poverty eradication and food security which is able to lead to sustainable economic growth and sustainable consumption and production. The philosophy greatly attaches to human development at all levels and emphasizes to strengthen community's capacity to ensure a balanced way of life and resilience.
\end{abstract}

Keywords

Poverty Eradication, Sufficiency Economy Philosophy, Sustainable Development Goals : Goal 1

Article Received: 10 August 2020, Revised: 25 October 2020, Accepted: 18 November 2020

\section{Introduction}

Half a billion people, or $8 \%$ of the total human population, could be pushed into poverty as economies around the world shrink because of the coronavirus pandemic. It would be the first time that poverty has increased globally in thirty years, since 1990. Poverty levels in developing countries could be set back by up to 30 years [1]. Thai economy is projected to grow by $4.1 \%$ in 2021 and by $3.6 \%$ in 2022, which represents a slow recovery to pre-COVID GDP output levels by mid-2022. It is estimated that 8.3 million workers will be unemployed or lose their income by the COVID-19 crisis, especially those in tourism and service sectors, at risk. The report finds that the number of economically insecure people, or those living below USD 5.5 per day (in purchasing power terms), is expected to double from 4.7 million people in the first quarter to 9.7 million people in the second quarter of 2020 [2].

Thailand has successfully reduced poverty over the past three decades from over 65\% in 1988 to under $10 \%$ in 2018. However, the poverty rate in Thailand increased from 7.2 percent to 9.8 percent during the past three years, and the absolute number of people living in poverty rose from 4.85 million to more than 6.7 million [3]. The growth of household incomes and consumption have stalled nationwide in recent years. This has made the poverty reduction in Thailand get reversed with the number of people living in poverty rising. Household debt level to gross domestic product (GDP) rose slightly to $80.1 \%$ in the first quarter of 2020, which is the highest level in four years.
According to Central bank data, the trend is going to continue as the coronavirus outbreak squeezes the economy and the economy could shrink a record $8.1 \%$. As of March, household debt stood at 13.479 trillion baht $(\$ 431.47$ billion). The debt to GDP ratio may jump to $88-90 \%$ at the end of 2020, which would be the highest in the 18 years [4]. During the hardship in Thailand in 1997 due to the economic uncertainties and risks caused by globalization, the Sufficiency Economy Philosophy has become Thailand's development compass. It directs the country with the primary aim to improve people's living conditions and develop the country economy based on the principles of moderation and avoiding redundancy. Particularly, the country advocates good management of risks and appropriate technology with special emphasis on inclusive decision-making, care for the environment, and the wellbeing of the marginalized people. Thailand's SEP experience is proof that the United Nations' 17 Sustainable Development Goals, especially "Goal 1: No poverty", could be attained when we believe that our people, our environmental and our future generations matter.

\section{The Sustainable Development Goals: Goal 1}

As of 2015, about 736 million people still live in poverty with less than US\$1.90 a day. Many of them lack of food, clean drinking water and sanitation. Although millions of people in many countries such as China and India have been lifted out of poverty, the progress has not been even. In some regions such as South Asia and sub-Saharan Africa, 
$80 \%$ of population still live in extreme poverty [5]. The Sustainable Development Goal (SDG) Goal 1 aims to end poverty in all its forms by 2030 . It targets to reduce the proportion of men, women and children of all ages who live in poverty at least by half; to implement nationally appropriate social protection systems and measures for all including substantial coverage of the poor and the vulnerable; to ensure equal rights to economic resources, to build the resilience of the poor and those in vulnerable situations; to ensure significant mobilization of resources from a variety of sources; and to create sound policy frameworks at the national, regional and international levels with the aim to end poverty [6].

There have been several agendas and commitments among member states to end poverty. At the Millennium Summit in September 2000, 189 countries unanimously adopted the Millennium Declaration, pledging to "spare no effort to free our fellow men, women and children from the abject and dehumanizing conditions of extreme poverty". This declaration was translated into an inspiring framework and into wide-ranging practical steps that helped to lift more than one billion people out of extreme poverty. Also, in "The Future We Want", the outcome document of Rio+20, Member States emphasized the highest priority to poverty eradication within the United Nations development agenda. Poverty eradication is also addressed in Chapter II of the Johannesburg Plan of Implementation (2002) [7].

The SDGs which is generally known as Global Goals, build on the Millennium Development Goals (MDGs). Its primary aim is to end all forms of poverty through cooperative efforts from all countries, poor, rich and middle-income to lift the impoverished out of poverty and promote prosperity as well as conserve the planet. Besides poverty eradication, they also call for actions from all countries to develop necessary strategies which promote economic growth and provide equal access to a range of social needs including health, social protection, education, and job opportunities, while conserving the nature and tackling climate change [8]. Although the world population living in extreme poverty reduced from $15.7 \%$ in 2010 to $10.0 \%$ in 2015 , the global poverty reduction rate has slowed down as the global poverty rate gets to $8.2 \%$ in 2019 . It is estimated that the 6 percent of global population will be living in extreme poverty in 2030, which is missing the target of SDGs to end poverty. In the situation of COVID-19 pandemic, it is assumed that the poverty rate possibly reaches $8.8 \%$ in 2020 unless the situation recovers very soon. This is the first rise in global poverty since 1998, and close to the 2017 level. About 71 million additional people are expected to be living in extreme poverty due to COVID-19. The largest increases in extreme poverty can be in Southern Asia and sub-Saharan Africa, with an additional 32 million and 26 million people, respectively as a result of the pandemic [9]. (as Figure 1)

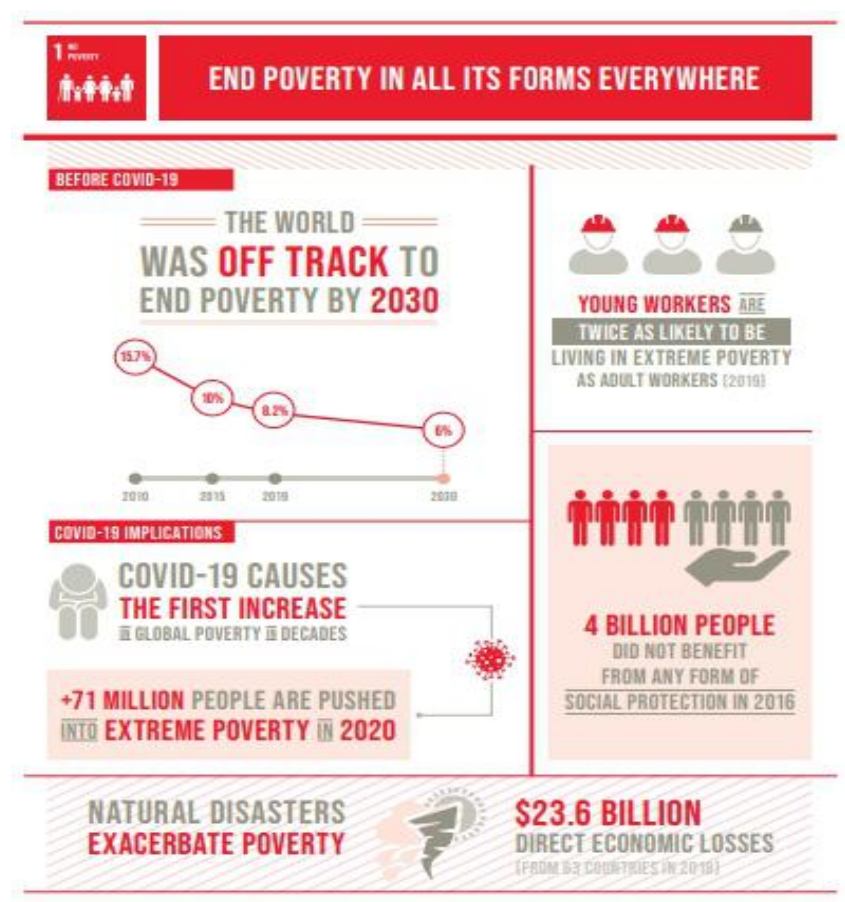

Figure 1. Overview infographic [10]

According to World Bank report, Thailand has been successful in reducing poverty over the past three decades from over $65 \%$ in 1988 to under $10 \%$ in 2018. However, there is no growth of national household income and consumption in recent years which makes poverty reduction reverse and more people living in poverty. From 2015 to 2018, Thailand's poverty rate increased from $7.2 \%$ to 9.8 $\%$, and the number of people living in poverty rose from 4.85 million to more than 6.7 million. The increase in poverty in 2018 was widespread in all regions, 61 out of 77 provinces. In the Central and Northeastern regions, the number of people living in poverty increased by over half a million in each region during the same period. And due to the conflict in the South, the region had the highest poverty rate for the first time in 2017 [11].

Thailand is the only nation in ASEAN experiencing several increases in poverty since 2000 . Over the past few years, Thailand's growth rate has been lower than other large economies in the developing East Asia and Pacific region. During the fourth quarter of 2019, the GDP growth rate in Thailand was at $2.7 \%$, the lowest rate among other countries in the region This shows that households are not resilient to sudden economic and environmental challenges. The income distribution of people at the bottom $40 \%$ was not in prosperity. And in the recent period of 2015-2017, consumption and income growth in this bottom $40 \%$ were negative. The main reason comes from the decline in labor incomes both in farming and business sections. Therefore, Thai households need better protection from income shortage such as ill-health, job-loss and natural disasters [12]. To eliminate constant poverty, it requires creation of more productive and higher-paying jobs and growth strategies for short-term risk alleviation and long-term investment. For short-term risk alleviation, Thailand needs to take immediate action in creating better jobs for the lowincome households. For long-term mitigation, there should be promotion for long-term investment to improve living standard of the poor, such as providing better health 
services, more educational opportunities, better welfare for aging population [13].

Elderly poverty now also becomes a global phenomenon, for example, South Korea has the highest poverty rate of people aged over 65 comparing to other countries in the Organization for Economic Co-operation and Development (OECD). In 2017, the country's elderly poverty rate reached $43.8 \%$ while the average poverty rate in the OECD was $13.5 \%$ [14]. Therefore, it is necessary to understand the effects of poverty in order to develop proper intervention strategies which aim to prevent and reduce the weaknesses caused by poverty [15].

The number of aged people In Thailand has reached 11.23 million, or $17.13 \%$ of the total population. Thailand will become an ageing society in 2021 when the number aged people will rise to 13.1 million or $20 \%$ of the total population, according to an NESDB report. In this number, those at age 70-79 and above 80, will account for $37.2 \%$ and $19.1 \%$ respectively. This make a combined $56.3 \%$ of the total aged population. This is a challenge for families, communities and the country because older people require more care for their welfare and assistance in their daily lives [16]. There are some guidelines for reducing the elderly poverty such as providing more jobs opportunities for the elderly; promoting lifelong education for preparedness into qualified and skilled elderhood; preparation before entering retirement; encouraging household saving; and reducing unexpected circumstances for household having the elderly. Governments also need to establish intervention programs to reduce the dependent household members and to monitor these households which are considered vulnerable to poverty [17].

Poverty has been one of crucial problems in Thai society for a long time. It requires immediate actions from all sectors involved, even individuals and households themselves. Only government itself cannot achieve the poverty eradication goals. To resolve poverty problems, people in communities and local authorities can collaborate with the government in finding solutions together via alternative paths that respond to the needs of people and their communities, for example, development program emerging from local wisdom, development program characterizing self-help and helping each other in the community, and development program conserving environments. Sufficiency economy philosophy can also be an effective alternative path for alleviating poverty among Thai farmers. Sufficiency economy villages supported by government policy are able to solve the problems of one village to the others sustainably.

\section{Introduction To Sufficiency Economy Philosophy}

Being concerned with the hardship of Thai farmers who were living in poverty when he ascended to the throne in 1946, King Bhumibol were keen on improving the living quality of Thai people in rural area. The per capita GDP of Thailand, at that time, was about US\$200. The king instituted a number of royal projects to help lots of the impoverished in rural area [18]. His royal projects aim to promote self-reliant or sustainable farming as well as protect critical natural resources.
In 1970s, Thailand faced many economic problems: oilprice spikes, decreasing US investment, budget deficits, inflation, and unstable domestic politics [19]. Sufficiency Economy Philosophy was first introduced during the King's speech to students in universities in 1974. He stated that development of the country had to proceed in stages. First, there has to be a foundation with the majority of the people having enough to live on by using methods and equipment in economical but technically correct ways. When the foundation is secure, then it can be gradually expanded and developed to raise prosperity and the economic standard to a higher level by stages [20]. As Thailand's economy took off with a strong component of agricultural exports, many farmers engaged in mono-cropping to pursue as much profit as possible. But when sudden changes occurred in the market and crop prices dropped, they suffered from debts and poverty. That convinced many farmers to try the Sufficiency Economy Philosophy. By doing integrated farming and reducing their dependence on single crop, many farmers recovered from the hardship and uplifted their families as well as were immune to the economic shocks.

In 1997, Thailand faced another critical financial crisis which was caused by many factors including economic growth slowing down in 1995, contraction in the real estate sector due to a constraint in market demand, the emergence of China as an intimidating competitor in international trade, and an appreciation of the dollars after Spring 1995. The real estate business had become unprofitable because too many houses and business buildings were built but the commercial vacancy rate went up to $15 \%$. The business owners, thus, were not able to pay back their debts to financial institutions. As the result, non-performing loans led to bank crisis. In international trade, Thailand's international trade had become less competitive due to the emerging trader, like China, and a constantly increasing trend of dollar currency which had worsened Thailand's terms of trade since the Spring of 1995 [21].

It is obvious that Thailand financial crisis in 1997 mainly caused by imbalanced economic and social development and too much dependence on international trade and foreign capital inflows. During the economic crisis in Thailand in 1997, the King reiterated his Sufficiency Economy Philosophy in his speech on December 4, 1997, "Recently, so many projects have been implemented, so many factories have been built, that it was thought Thailand would become a little tiger, and then a big tiger. People were crazy about becoming a tiger...Being a tiger is not important. The important thing for us is to have a sufficient economy. A sufficient economy means to have enough to support ourselves." [22] During the hardship caused by 1997 crisis, Sufficiency Economy Philosophy caught more attention from academics, government officials, private enterprises, and even local people. For years, it has been proved that Sufficiency Economy Philosophy is not limited only to the agricultural or rural sectors but it can be applied to all levels, branches, and sectors of the economy including the investment, financial, the real estate, and the international trade. 


\section{Sufficiency Economy: A Practical Guidance For Poverty Eradication}

The Sufficiency Economy Philosophy's central goal is to alleviate poverty and hardship among Thai people. King Rama IX formulated the philosophy not in the comfort of a palace, but in the remote areas by working with poor villagers in every corner of his kingdom over a period of decades; researching, experimenting, using trial and error to find what works with the participation and feedback from the villagers themselves. The Sufficiency Economy focuses on human well-being, emphasizes human security and environmental sustainability, and concentrates on human development. Sufficiency Economy principles has been proved applicable for household, communities, and the country through 4,000 royal development projects and 8,000 model Sufficiency Economy Villages. The pilot projects that proved successful were often adopted and scaled up by the government to amplify and extend their benefits to more people nationwide.

Sufficiency Economy philosophy highlights a balanced way of living, or the Buddhism's middle path. It emphasizes the sufficient livelihood and cooperation at the local level as well as allows the nation to modernize without resisting globalization. At the same time, it strengthens the communities and the country to counteract negative outcomes from rapid economic, cultural, and environmental changes [23]. At the individual and household level, it guides people and families to live in a more self-reliant way with less dependence. At community level, it promotes sharing and cooperation within the community as well as be immune from sudden economic and politic changes. At the national level, it strengthens the nation economic system and increase human capital of the country as well as promote environmental sustainability.

The levels of success of poverty eradication based on Sufficiency Economy Philosophy can be varied depending on different factors including being insightful, honesty and perseverance, reasonableness in investment and consumption, and teamwork and goal sharing. Either an individual, household, community, or country, should understand what they have on hand to start with and what they are going to do. They should learn from their experience of economic activities and be insightful when making decision. Honesty and perseverance are required. When their decision does not work or the outcome is not going as plan, they should accept and put their efforts to correct it and work hard to accomplish. They should be reasonable when making an investment and not spend on unnecessary things or spend more than what they can earn. Teamwork and goal sharing is also an important key to success in poverty reduction according to Sufficiency Economy Philosophy [24]. (Figure 2)

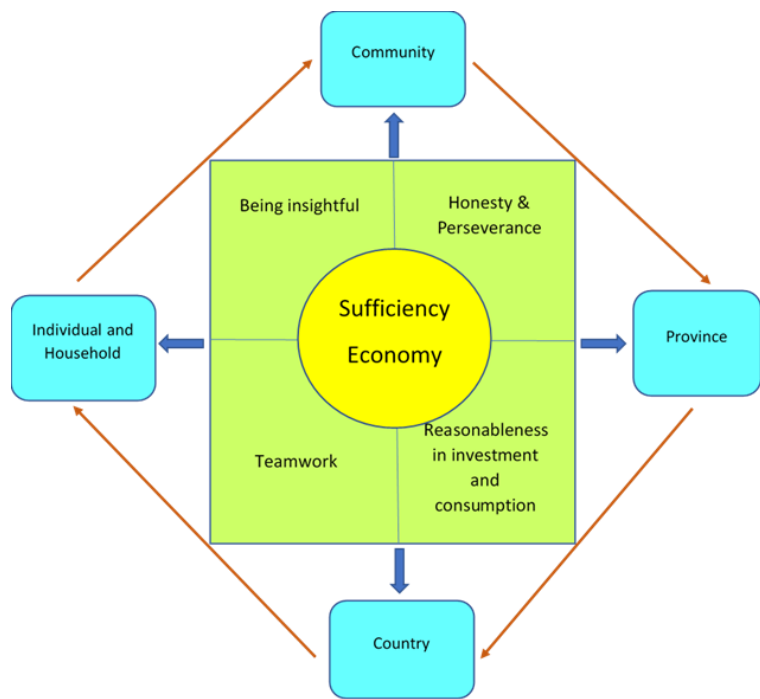

Figure 2. Key Elements for Successful Poverty Eradication based on Sufficiency Economy Philosophy

To achieve long-term poverty eradication at the local and national level based on Sufficiency Economy Philosophy, government may need to establish effective plans at early step including Management of Community's Natural Resources and Environment, Community's Business Support for Poverty Solving, Development of Local Administration for Poverty Solving, and Increases of the Poor's Efficiency and Potential. Therefore, the community can have an effective poverty reduction system and use local resources effectively [25]. (Figure 3)

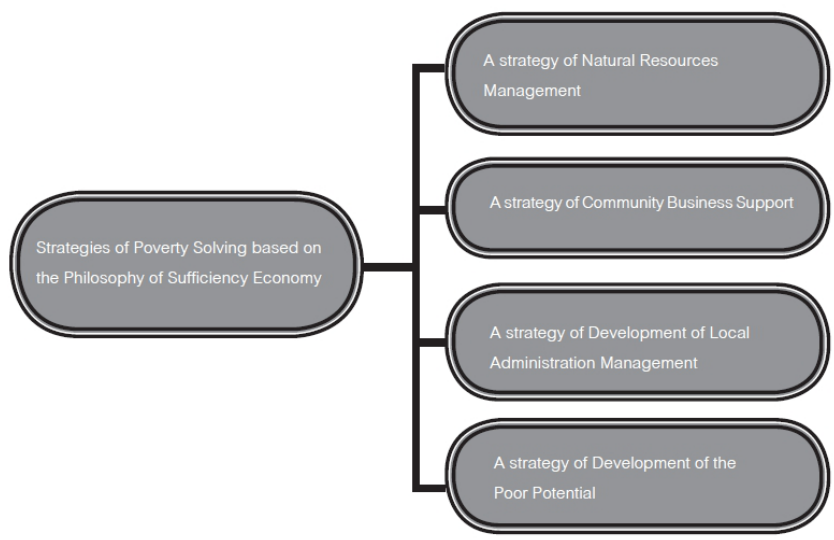

Figure 3. Strategies of Poverty Solving based on the Philosophy of Sufficiency Economy [26]

Recent economic, labor market, environmental challenges and COVIC-19 pandemic reveal that Thai households are vulnerable to falling back into poverty. Persistent poverty and inequity can be intensified by employment in the low productivity agriculture sector, an aging society, lagging regions and heterogenous access to services. Trends in economic growth and perceptions from 2018 and onward indicate that households will continue to face challenges. Aside from improving policies on safety nets, targeting, and risk mitigation to help the vulnerable, longer-term strategies are also necessary. These longer-term strategies will involve, among other things, investing in the next generation. Sufficiency Economy principles should be adopted and practiced at all levels in different sectors of 
Thai economy. Thai government, local authorities, and communities should seriously implement this economic philosophy to alleviate the current problems of poverty and promote well-being of Thai people in the future.

\section{Conclusion}

Poverty has been one of crucial challenges for many countries, especially in South Asia and sub-Saharan Africa. Unproductive farming due to climate changes and economic downturn are main reasons making millions of people live in poverty. The COVID-19 pandemic has also worsened the situation due to its both immediate and long-term economic consequences for people across the globe. Life worldwide has recently changed drastically. The COVID-19 pandemic has been threatening not only healthcare systems, but also the stability of economies and the livelihoods of citizens. Countries requires strong social protection systems for alleviating the effects and preventing many people from trapping in poverty. What can be an effective system for preventing from falling into poverty?

Sufficiency Economy can be an answer to this puzzle because it offers a practical guideline for people to live their lives in a sufficient manner. It is practical, simple to implement, and flexible to different challenges. It highlights a balanced way of living and emphasizes the sufficient livelihood with cooperation at the local level. With its core principles of moderation, reasonableness, the need of selfimmunity, individuals can be self-reliant with sufficient protection from impact arising from internal and external changes. However, they need to be insightful, honest and persevere. Also, they need to make a reasonable investment and consumption as well as work together with others.

The hard time when Thailand faced the economic crisis in 1997, people, businesses, and government realized that the economy was unbalanced and unsustainable. Sufficiency Economy Philosophy encourages people to be moderate, prudent, and self-immune to sudden changes and difficulties. When facing hardship, it guides people to persevere and strive on. While Thailand economy suffered from economic pain, the government and businesses started to embrace sufficiency economy and established effective measures to ensure good governance, including the bottomup decision-making with respect for local wisdom and knowledge, as well as listening to people and businesses voices. Since then, the Sufficiency Economy Philosophy has been taken as guideline for country's development as it directs the country with the common intention of development based on the principles of moderation and avoiding redundancy. Understanding of SEP is found to be one of the key factors having influence on people's wellbeing and enabling Thailand to pursue a balanced and sustainable development. It is adaptable to any unforeseen events, whether an economic crisis, a natural disaster, or a social dilemma. Ultimately, by putting the Sufficiency Economy into practice, the well-being of the Thai people will be improved and poverty will eventually be eradicated.
References

[1] Ahmed, K. (2020). Coronavirus could turn back the clock 30 years on global poverty. Retrieved 20 August 2020 from https://www.theguardian.com/globaldevelopment/2020/apr/09/ coronaviruscould-turn-back-the-clock-30-years-onglobal-poverty

[2] Office of the National Economic and Social Development Council. (2020). The Thai Economy in Q2/2020 and the Outlook for 2020. Bangkok: NESDC News.

[3] The World Bank. (2020). Thailand's Poverty on the Rise Amid Slowing Economic Growth. Retrieved 19 August 2020

from

https://www.worldbank.org/en/news/pressrelease/ 2020/03/03/thailands-poverty-onthe-rise-amid-slowing-economic-growth

[4] Reuters. (2020). Q1 household debt at $80 \%$ of GDP, highest in 4 years. Retrieved 19 August 2020 from https://www.bangkokpost.com/business/19 47380/q1-household-debt-at-80-of-gdphighest-in-4-years

[5] UN. (2020). World social report 2020: Inequality in a rapidly changing world. https://www.un.org/development/desa/dsp d/wpcontent/uploads/sites/22/2020/02/WorldSocial-Report2020ExecutiveSummary.pdf

[6] https://www.undp.org/content/undp/en/ho me/sustainable-development-goals/goal-1no-poverty/targets.html

[7] https://sdgs.un.org/topics/povertyeradication

[8] UN. (2019) Potential impact of later childbearing on future population. Population Facts.

[9] https://www.un.org/sustainabledevelopme $\mathrm{nt} / \mathrm{wp}-$ content/uploads/2019/07/E_Infographic_0 1.pdf 
[10] OECD. (2020), Poverty rate (indicator). Retrieved 17 August 2020 from doi: 10.1787/0fe1315d-en

[11] Hin Moi Youn \& et al. (2020). The impact of poverty transitions on frailty among older adults in South Korea: findings from the Korean longitudinal study of ageing. BMC Geriatrics. 20 (139): 1-10.

[12] Charoensuthipan, P \& Katharangsiporn, K. (2019). A society of seniors requires special treatment. Retrieved 17 August 2020

from

https://www.bangkokpost.com/business/

1722603/a-society-of-seniors-requiresspecial-treatment

[13] Leetrakun, P. (2019). An analysis of the poverty in elderly in Chiangrai province. Journal of Humanities and Social Sciences. 11 (22): 95- 110.

[14] South-South in Action; Sustainability in Thailand; Experience for Developing Countries (PDF). New York: United Nations Office for South-South Cooperation and Ministry of Foreign Affairs of Thailand. 2017. Retrieved 2 March 2017.

[15] Thailand Human Development Report 2007; Sufficiency Economy and Human Development (PDF). Bangkok: United Nations Development Program (UNDP). 2007. ISBN 974-88126-3-4. Retrieved 10 December 2016.

[16] https://en.wikipedia.org/wiki/Sufficiency_ economy\#cite_note-UNDP-2007-2.

[17] http://www.columbia.edu/cu/thai/html/fina ncial97_98.html

[18] https://en.wikipedia.org/wiki/Sufficiency_ economy\#cite_note-UNDP-2007-2.

[19] Kansuntisukmongkol, K. (2017). Philosophy of sufficiency economy for community-based adaptation to climate change: Lessons learned from Thai casestudies. Kasetsart Journal of Social Sciences. 38 (2017) 56-61.

[20] Mongsawad, Prasopchoke: Asia-Pacific Development Journal Vol. 17, No. 1, June 2010, p. 131
[21] Insawan, N. (2015). Research and Development for Poverty Reduction of the Community in the Place of Civilisation with the Philosophy of the Sufficiency Economy. Ratchaphruek Journal. 13 (1): 1-10.

[22] https://so05.tcithaijo.org/index.php/Ratchaphruekjournal/ article/view/240940/164065 